\title{
Properties of Al6063 MMC Reinforced With Zircon Sand and Alumina
}

\author{
J.Jenix Rino ${ }^{1}$, Dr.D.Sivalingappa ${ }^{2}$, Halesh Koti $^{3}$, V.Daniel Jebin ${ }^{4}$ \\ ${ }^{1,4} P G$ scholar, ${ }^{2,3}$ Professor, \\ Department of Mechanical Engineering, Adhiyamaan College of Engineering(Autonomous), Hosur, India.
}

\begin{abstract}
The present study deals with the investigation of the mechanical behaviour of Aluminium6063 alloy composites reinforced by Zircon sand $\left(\mathrm{ZrSiO}_{4}\right)$ and Alumina $\left(\mathrm{Al}_{2} \mathrm{O}_{3}\right)$ particles with a total reinforcement in Wt\% is 8 , and in this hybrid reinforcement the variations $(0+8) \%,(2+6) \%,(4+4) \%,(6+2) \%,(8+0) \%$ were taken in to account for investigating the properties such as density tensile strength and hardness of the composites synthesized by Stir casting technique. The mechanical properties evaluation reveals variations in hardness and the tensile strength values with the composite combinations. From the experimental studies, the optimum volume fraction of hybrid reinforcement in Al 6063 alloy on the basis of microstructure and mechanical properties it is found that the $(4+4) w t \%$ combination.
\end{abstract}

Keywords: Hybrid reinforcement, Stir casting, Mechanical properties,

\section{Introduction}

The unique tailorability of the composite materials for the specific requirements makes these materials more popular in a variety of applications such as aerospace, automotive (pistons, cylinder liners, bearings), and structural components, resulting in savings of material and energy [1,11]. Discontinuous reinforced aluminum metal matrix composites (DRAMMCs) are a class of composite materials having desirable properties like low density, high specific stiffness, high specific strength, controlled co-efficient of thermal expansion, increased fatigue resistance and superior dimensional stability at elevated temperatures etc. $[3,8]$ The properties and behavior of various $\mathrm{Al}$ alloys and their composites are much explored in terms of microstructure, mechanical properties, loading conditions and applications [5,6,12].

This investigation is to study the behaviour of binary and ternary composites reinforced by Zircon sand $\left(\mathrm{ZrSiO}_{4}\right)$ and Alumina $\left(\mathrm{Al}_{2} \mathrm{O}_{3}\right)$ particles having the size of 44 microns and 2 microns respectively.

\subsection{Alumina $\left(\mathrm{Al}_{2} \mathrm{O}_{3}\right)$ :}

\section{Materials}

Aluminium oxide is an electrical insulator but has a relatively high thermal conductivity (30 Wm-1K-1[12]). In its most commonly occurring crystalline form, called corundum or $\alpha$-aluminium oxide, its hardness makes it suitable for use as reinforcing agent in MMC Aluminium oxide is responsible for the resistance of metallic aluminium to weathering, Since Metallic aluminium is very reactive with atmospheric oxygen.

Table.1: Properties of Alumina

Properties

M.P. $\left({ }^{0} \mathrm{C}\right)$

Limit of application $\left({ }^{0} \mathrm{C}\right)$

Hardness (Moh's Scale)

Density $\left(\mathrm{g} / \mathrm{cm}^{3}\right)$

Linear coefficient of expansion $\left(\mu \mathrm{m} / \mathrm{m}{ }^{0} \mathrm{C}\right)$

Fracture toughness $\left(\mathrm{MPa}-\mathrm{m}^{1 / 2}\right)$

colour

Alumina
2072
1175
7.5
3.69
4.5
3.5
White

2.2 $\mathrm{Zircon} \operatorname{Sand}\left(\mathrm{Zr}_{2} \mathrm{SiO}_{4}\right)$ :

Zircon Sand consists of mostly ZIRCONIUM SILICATE ( $\mathrm{ZrSiO} 4)$ and some hafnium in addition to some rare earth elements, titanium minerals, monazite, etc. Zircon Sand is used chiefly for facing on foundry moulds 
to increase the resistance against metal penetration. Milled Zircon Sand is used in refractory paint for coating the outside of moulds.

Zircon Sand deposits have been found in abundance near Indian coastal regions of Kerala, Tamil Nadu and Orissa. Zircon Sand was found to be a promising candidate as reinforcement material for aluminium, zinc and lead based composites. [11]

Table.2: Properties of Zircon sand

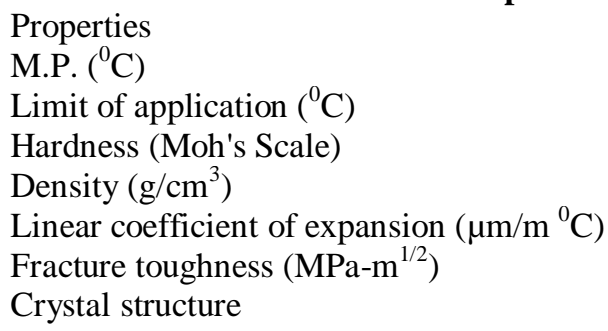

$$
\begin{aligned}
& \text { Zircon Sand } \\
& 2500 \\
& 1870 \\
& 7.5 \\
& 4.5-4.70 \\
& 4.5 \\
& 5
\end{aligned}
$$

Tetragonal

\subsection{Al6063:}

Aluminium alloys are alloys in which $\mathrm{Al}$ is the predominant metal. The typical alloying elements are copper, magnesium, manganese, silicon, and zinc where the silicon and magnesium plays major role[3].

Table.3: Chemical Composition of Al 6063 Alloy

$\begin{array}{cccccc}\mathbf{S i} & \mathbf{F e} & \mathbf{C u} & \mathbf{M n} & \mathbf{M g} & \mathbf{C r} \\ 0.431 & 0.102 \% & 0.0073 \% & 0.029 \% & 0.50 \% & 0.0026 \% \\ \mathbf{~ N i} & \mathbf{C o} & \mathbf{C d} & \mathbf{Z n} & \mathbf{L i} & \mathbf{A l} \\ 0.0036 \% & <0.001 \% & <0.0001 \% & 0.0049 \% & <0.0002 \% & 98.8 \%\end{array}$

Table.4: Composition of matrix and reinforcement in wt\%

$\begin{array}{cccc}\text { Samples } & \mathrm{Al} 6063 \text { in } \% & \mathrm{ZrSiO}_{4} \text { in } \% & \mathrm{Al}_{2} \mathrm{O}_{3} \text { in } \% \\ \mathbf{1} & 92 & - & 8 \\ \mathbf{2} & 92 & 2 & 6 \\ \mathbf{3} & 92 & 4 & 4 \\ \mathbf{4} & 92 & 6 & 2 \\ \mathbf{5} & 92 & 8 & -\end{array}$

\subsection{Processing:}

III. Methods:

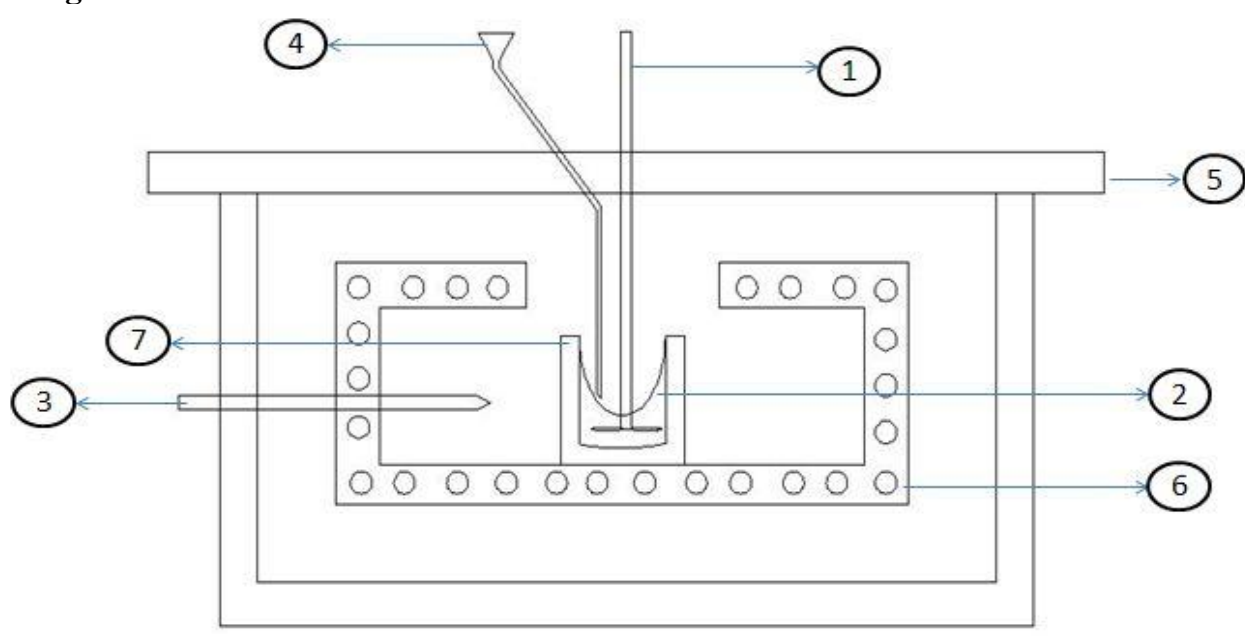

1.Shaft. 2.Molten metal. 3.Thermocouple. 4.Particle incorporating chamber. 5.Refractive shielding. 6. Heating coil. 7.Graphite crucible.

Fig.1: Stir casting setup 
Stir Casting is a method of composite materials fabrication via liquid state in which dispersed phase of $\mathrm{ZrSiO}_{4}$ and $\mathrm{Al}_{2} \mathrm{O}_{3}$ particles were mixed with the molten Al6063 alloy by means of mechanical stirring inside a graphite crucible kept inside an electric resistance furnace as shown in fig.1. The liquid composite material is then cast by pouring the molten metal in to the mould. The stirrer speed is adjusted for getting the vertex formation of molten metal and which is positioned such as $60 \%$ of melt is above the stirrer for enhancing good reinforcement dispersion. The processing temperature maintained between $765-775^{\circ} \mathrm{C}$ and the reinforcing agents were preheated for $400^{\circ} \mathrm{C}$ to avoid the oxide layer formation over the particles, the particle feed rate to the molten matrix is fixed as 20 grams per minute. Scum powder and Hexo- cloro ethane were used as slag removing and degassing agents.

The processing variables such as Speed of stirrer, Processing temperature, Pouring speed, Mould temperature, reinforcement feed rate, incubation time are have to be considered for developing a good composite[5]

\subsection{Density measurement:}

The density of the specimens were estimated both theoretically and practically by Rule of mixture and Archimedes' principle.

$$
\text { R.O.M : } \rho_{\mathrm{c}}\left(\mathrm{V}_{\mathrm{m}}+\mathrm{V}_{\mathrm{p} 1}+\mathrm{V}_{\mathrm{p} 2}\right)=\rho_{\mathrm{m}} \mathrm{V}_{\mathrm{m}}+\rho_{\mathrm{p} 1} \mathrm{~V}_{\mathrm{p} 1}+\rho_{\mathrm{p} 2} \mathrm{~V}_{\mathrm{p} 2}
$$

$\rho_{\mathrm{c}}$ - Density of composite, $\rho_{\mathrm{m}}$ - Density of Matrix, $\rho_{\mathrm{p} 1,2}$ - Density of reinforcing particles

$\mathrm{V}_{\mathrm{m} \text { - Volume of matrix, }} \mathrm{V}_{\mathrm{p} 1,2 \text { - Volume of reinforcing particles }}$

\subsection{Brinell Hardness Test:}

Test material was indented with a $5 \mathrm{~mm}$ diameter hardened steel ball subjected to a load of $150 \mathrm{~N}$ applied for 10 seconds. The diameter of the indentation left in the test material is measured with a low powered microscope. Brinell harness number is calculated by dividing the load applied by the surface area of the indentation. The diameter of the impression is the average of five readings at right angles.

\subsection{Tensile test:}

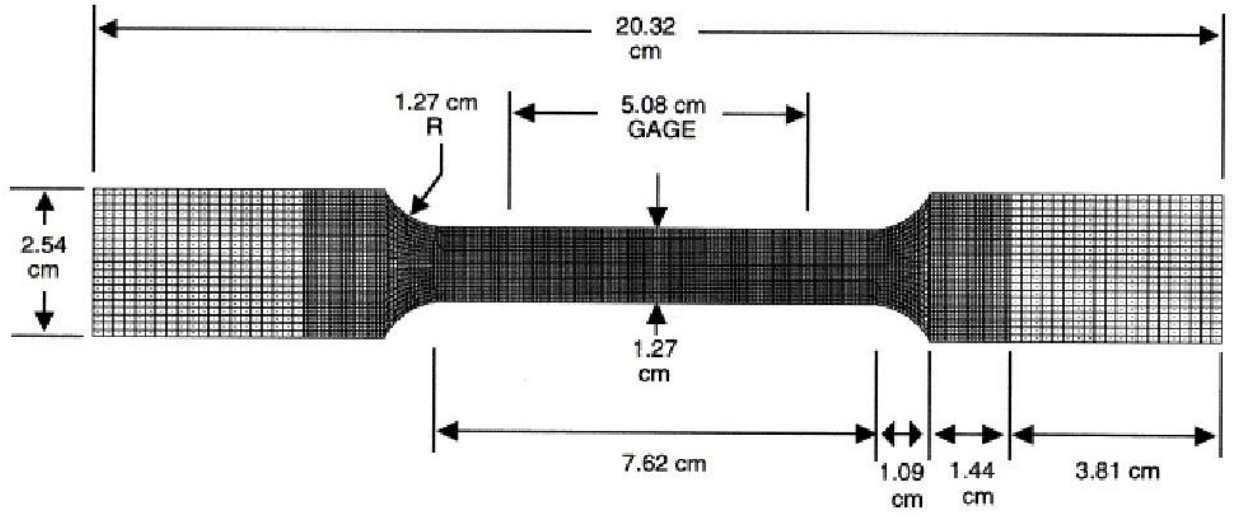

Fig.2: Tensile specimen ASTM E8

The room temperature tensile test was conducted using Universal testing machine. The as-cast Aluminium6063 alloy composite samples for tensile test were prepared using CNC lathe according to ASTM E8, as shown in Fig. 2.The tests were conducted trice to get the average response value.

\subsection{Density and hardness:}

Samples
$\mathbf{1}$
$\mathbf{2}$
$\mathbf{3}$
$\mathbf{4}$
$\mathbf{5}$

\section{Results And Discussion:}

Table.5: Density comparison

Theoretical Experimenta
Density $\mathrm{gm} / \mathrm{cm}^{3} \quad$ Density $\mathrm{gm} / \mathrm{cm}^{3}$
2.769
2.793
1.228
2.778
2.802
0.864
2.785
2.795
0.718
2.794
2.822
1.002
2.802
2.838
1.282

Porosity

$\%$

The porosity is calculated by using the formula 
$\%$ of Porosity $=($ Difference in Density/ Theoretical Density $) * 100$

The comparison of theoretical and experimental density has been given in the table.5, from table it is understood that the porosity in the composite is less especially low in the hybrid composites $2,3,4$ comparing to $1 \& 5$.

\subsection{Hardness:}

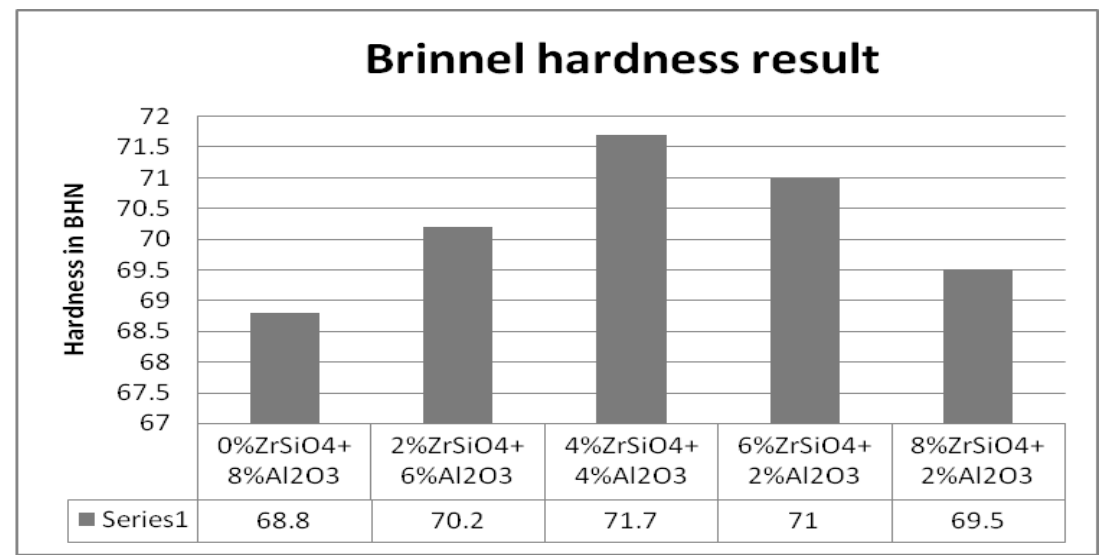

Fig.3: Hardness chart of the composites

Fig.2 shows the hardness result in terms of BHN along $\mathrm{Y}$ axis, the hardness of the composite sample having $4 \% \mathrm{ZrSiO}_{4}+4 \% \mathrm{Al}_{2} \mathrm{O}_{3}$ have the higher hardness value followed by sample having $6 \% \mathrm{ZrSiO}_{4}+2 \% \mathrm{Al}_{2} \mathrm{O}_{3}$ sample having $2 \% \mathrm{ZrSiO} 4+6 \% \mathrm{Al}_{2} \mathrm{O}_{3}$ sample having $8 \% \mathrm{ZrSiO}_{4}+0 \% \mathrm{Al}_{2} \mathrm{O}_{3}$ sample having $0 \% \mathrm{ZrSiO}_{4}+8 \% \mathrm{Al}_{2} \mathrm{O}_{3}$.

\subsection{Tensile strength:}

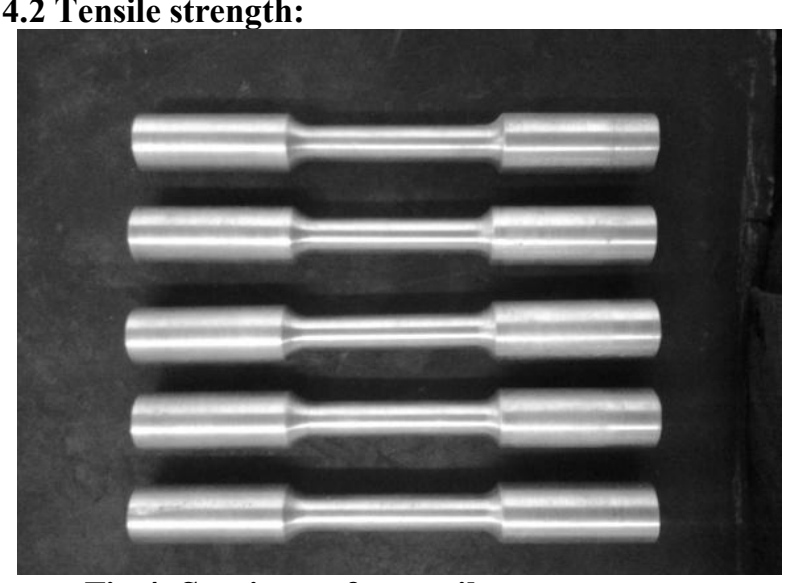

Fig.4: Specimens for tensile test

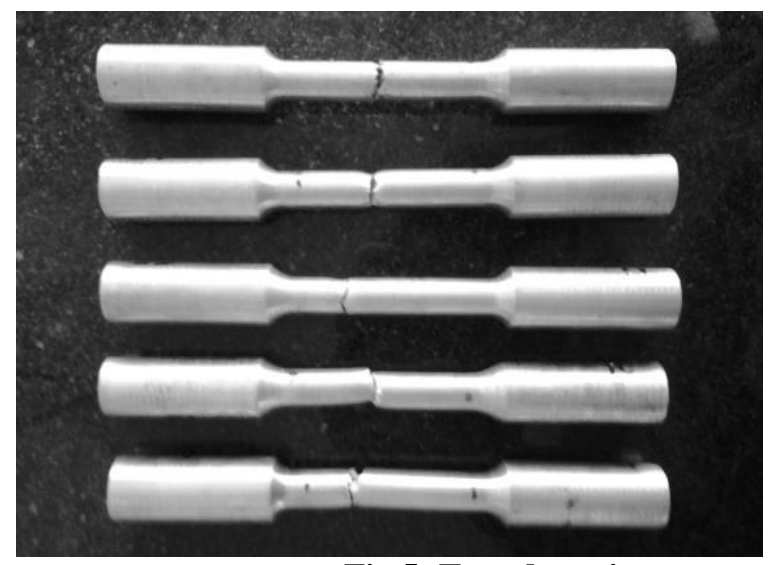

Fig.5: Tested specimens

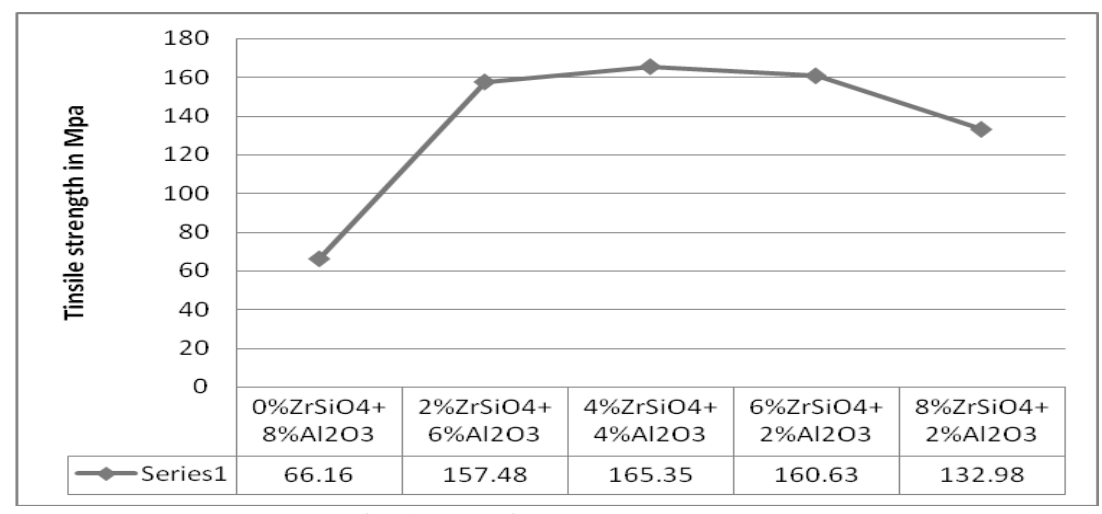

Fig.6: Tensile strength graph

Usually the tensile property of the composite will get loose on addition of reinforcement, the same has been happened in the Zircon sand alone and Alumina alone reinforced composites. the Resultant graph shows the peak value in the $4 \% \mathrm{ZrSiO} 4+4 \% \mathrm{Al}_{2} \mathrm{O}_{3}$ also the hybrid reinforced composites having higher tensile strength over the Zircon sand alone and Alumina alone reinforced composites. 


\subsection{Distribution:}

The Scanning electron micro graphs were taken for analysing the distribution of the reinforcement and the formation of pores and clusters.

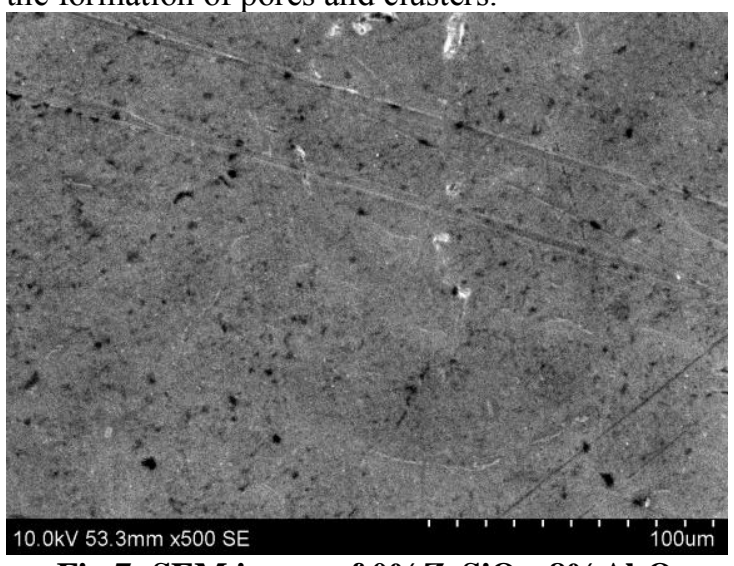

Fig.7: SEM image of $0 \% \mathrm{ZrSiO}_{4}+8 \% \mathrm{Al}_{2} \mathrm{O}_{3}$

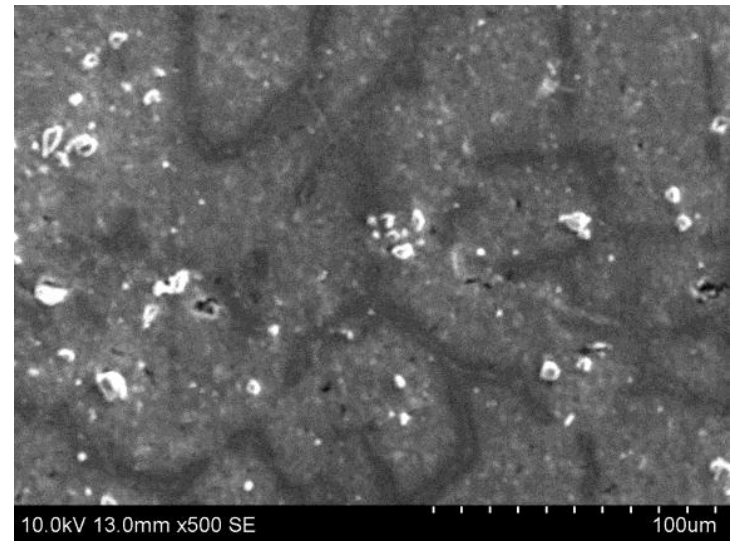

Fig.9: $\mathrm{SEM}$ image of $4 \% \mathrm{ZrSiO}_{4}+4 \% \mathrm{Al}_{2} \mathrm{O}_{3}$

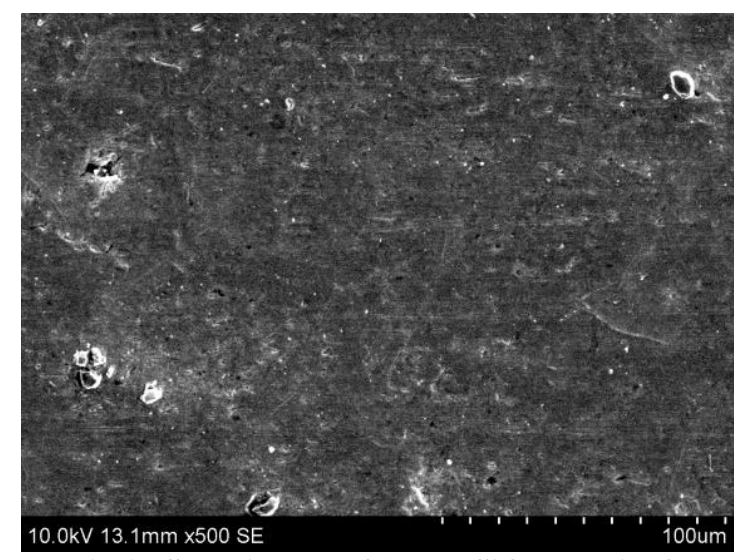

Fig.8: SEM image of $2 \% \mathrm{ZrSiO}_{4}+6 \% \mathrm{Al}_{2} \mathrm{O}_{3}$

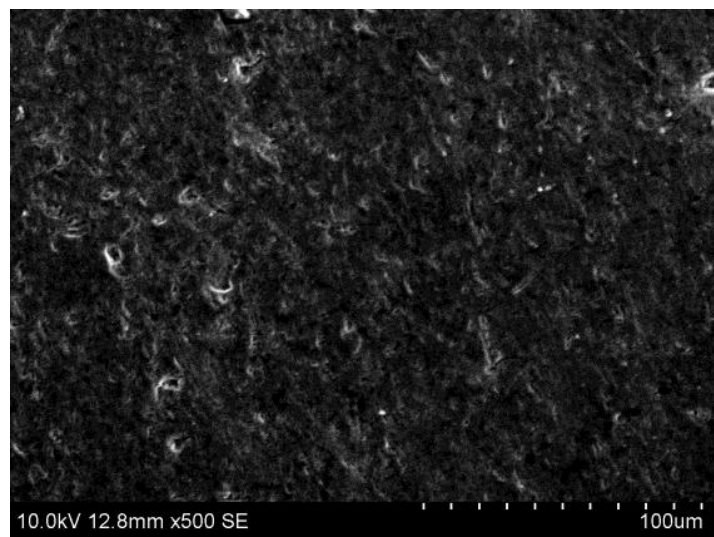

Fig.10: $\mathrm{SEM}$ image of $6 \% \mathrm{ZrSiO}_{4}+2 \% \mathrm{Al}_{2} \mathrm{O}_{3}$

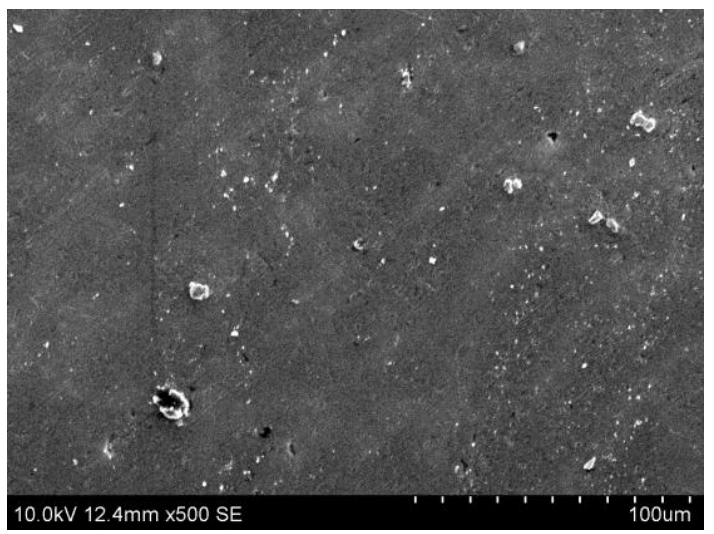

Fig.11: SEM image of $8 \% \mathrm{ZrSiO}_{4}+0 \% \mathrm{Al}_{2} \mathrm{O}_{3}$

from the SEM images we can see the uniform distribution of the reinforcement in the matrix alloy also the inter metallic formation in the hybrid reinforced composites, the pore formation in the 8\%Alumia reinforced composite is more than the other samples and the particles were well embedded in the $6 \% \mathrm{ZrSiO}_{4}+2 \% \mathrm{Al}_{2} \mathrm{O}_{3}$ reinforced composite, in $4 \% \mathrm{ZrSiO}_{4}+4 \% \mathrm{Al}_{2} \mathrm{O}_{3} \& 2 \% \mathrm{ZrSiO}_{4}+6 \% \mathrm{Al}_{2} \mathrm{O}_{3}$ reinforced composite there are uniform inter metallic formation with minimum pores.

\section{Conclusion:}

Al 6063 alloy matrix hybrid composites reinforced with Zircon Sand particles and Alumina particles has been successfully synthesized by the stir casting method. The results reveals the hybrid reinforced composites have the property improvement better than Zircon sand and Alumina particles alone reinforced 
composites, the hardness and the tensile strength of the composite having the higher value at the composite sample having the reinforcement combination of $4 \% \mathrm{ZrSiO} 4+4 \% \mathrm{Al}_{2} \mathrm{O}_{3}$ in its $\mathrm{wt} \%$, also in which combination the particle dispersion is uniform and the pores are less where inter metallic's formed.

\section{Acknowledgement}

We wish to thank Mr.T.Dominic Savio General manager of General foundries, Bommachandra, Bangalore, India. for permitting us to perform the tests in their esteem laboratory.

\section{References}

[1] Daniel B. Miracle and Steven L. Donaldson, "Introduction to Composites", ASM Hand Book of Composite Materials, volume-21.

[2] Ibrahim, I. A., Mohamed, F. A., Lavernia, E. J., 1991, "Metal Matrix Composites" A Review Journal of Material Science, Vol.26, pp. $1137-1157$.

[3] J.Jenix Rino, D.Chandramohan, K.S.Sucitharan, V.Daniel Jebin"An Overview On Development Of Aluminium Metal Matrix Composites With Hybrid Reinforcement" IJSR, India online ISSN:2319-7064.

[4] Kandil, A., Effect of SiC Particulates as Reinforcement on the Aging Behavior and Mechanical Properties of Aluminum Alloy Composites, Metal Volume 58 (11) (2004) 721-726.

[5] Materials for Transportation Technology, Edited by P.J. Winkler (2000),Wiley-VCH.

[6] Nigamanada ray, Dilipkumarkerketta, "Some Studies on Aluminium Matrix in Situ Composites Produced by Stir Casting Method", ME Thesis NIT Rourkela, 2010.

[7] Sinclair, I., Gregson, P. J., 1997, "Structural Performance of Discontinuous Metal Matrix Composites" Material Science and Technology, Vol. 3, pp. $709-725$.

[8] S. Sankaranarayanan R. Karthigeyan G. Ranganath "Mechanical Properties and Microstructure Studies of Aluminium (7075) Alloy Matrix Composite Reinforced with Short Basalt Fibre" European Journal of Scientific Research ISSN 1450-216X Vol.68 No.4 (2012), pp. 606-615.

[9] Sudipt Kumar, J. AnandaTheerthan, "Production and Characterisation of Aluminium-Fly Composites using Stir Casting Method", Department of Metallurgical \&Materials Engineering National Institute of Technology Rourkela, 2008.

[10] Taha, A. Mohamed, Materials and Design, Vol. 22 (2001) pp 431- 441.

[11] Wang, Y.-Q., Song, J.-I., Dry Sliding Wear Behavior of Al2O3 Fibre and SiC Particle Reinforced Aluminum based MMCs Fabricated by Squeeze Casting Method, Transactions of Nonferrous Metals Society of China, 21 (7) (2011) 1441-1448. 